\title{
Duplex real-time PCR methods for molecular detection and characterization of canine tick-borne haemoparasites from Punjab state, India
}

\author{
Aparna M. Thomas ${ }^{1} \cdot$ Harkirat Singh $^{1} \mathbb{D} \cdot$ Harsh Panwar $^{2} \cdot$ Ram S. Sethi $^{3} \cdot$ Nirbhay K. Singh $^{1}$
}

Received: 30 July 2021 / Accepted: 18 February 2022 / Published online: 1 March 2022

(c) The Author(s), under exclusive licence to Springer Nature B.V. 2022

\begin{abstract}
Background Microscopy is a routinely used technique for the diagnosis of canine tick-borne haemoparasitic diseases in various clinical laboratories worldwide. In an attempt to provide better diagnostic assay to the clients for effective management of these diseases duplex real-time PCR assays were applied.

Methods and results Blood samples $(\mathrm{n}=338)$ aseptically collected from suspected dogs of Central Plain Zone of Punjab state, India were subjected to SYBR Green based real-time duplex PCR assays for simultaneous detection of B. vogeli \& E. canis and B. gibsoni \& H. canis. Results revealed an overall prevalence rate of canine tick-borne haemoparasites as $54.1 \%$, amongst which H. canis was the predominant (25.4\%), followed by B. gibsoni (16.3\%), E. canis (10.7\%) and B. vogeli (1.8\%). Sensitivity and specificity of the duplex assays ranged from 59.04 to $100.0 \%$ and 58.12 to $92.52 \%$, respectively and their strength of agreement was "fair" with kappa value statistics. A significant $(p<0.05)$ association between prevalence of $B$. gibsoni, H. canis and E. canis infection with risk factors like sex, breed, season and location was recorded. The ancestral background of the field isolates of haemoparasites was also studied by phylogenetic analysis of their nucleotide sequences. Conclusions SYBR Green dye based duplex real-time PCR assays proved to be highly sensitive, specific, rapid and affordable diagnostic tests for use by clinicians to save the life of pets.
\end{abstract}

Keywords Canine haemoparasites $\cdot$ Duplex real-time PCR assays $\cdot$ Molecular characterization $\cdot$ Risk factors

\section{Introduction}

Tick-borne diseases are amongst the most important emerging problems in dogs worldwide particularly in the tropical and semi-tropical regions. The geo-climatic conditions of the Indian sub-continent, including Punjab state, characterized by high humidity and ambient temperature for most parts of the year is highly conducive for development and

Harkirat Singh

drharkiratsingh@hotmail.com

1 Department of Veterinary Parasitology, Guru Angad Dev Veterinary and Animal Sciences University, Ludhiana, Punjab 141004, India

2 Department of Dairy Microbiology, Guru Angad Dev Veterinary and Animal Sciences University, Ludhiana, Punjab 141004, India

3 Department of Animal Biotechnology, Guru Angad Dev Veterinary and Animal Sciences University, Ludhiana, Punjab 141004, India propagation of ticks [1]. The brown dog-tick Rhipicephalus sanguineus sensu lato acting as a common vector for several pathogens in dogs often leads to multiple infections upon exposure. The important canine tick-borne pathogens include Babesia spp., Ehrlichia spp. and Hepatozoon canis and co-infections of these parasites have been reported especially in the endemic areas [2].

Conventional microscopic detection of parasites is considered as the "gold standard" test but has limited utility in sub-clinical or chronic cases owing to its lower sensitivity [3]. Serological assays like enzyme linked immunosorbent assay (ELISA), indirect fluorescent antibody test (IFAT), and immunoblot assays are sensitive, but suffer from the problem of cost incurred, cross-reactivity and inability to distinguish between present or past infection [4]. However, molecular diagnostic techniques, like conventional polymerase chain reaction (PCR) and real-time PCR assays offer sensitive and specific diagnostic tests for detection of the pathogens. 
Recently, conventional singleplex PCR assays have been extensively used for the detection of E. canis, Babesia spp. and $H$. canis in dogs from India [5] particularly Punjab state [6-10]. Although, multiplex PCR assays for simultaneous detection of these pathogens would save time, labour and cost but there are limited reports on development and application of these assays from the region [11-13]. In contrast to conventional PCR approach, the real-time PCR assay has an advantage of monitoring the formation of target specific amplicon throughout the reaction and can hence replace these diagnostic protocols [14]. As scanty literature is available regarding the use of multiplex real-time PCR assays [15-17], the present study was aimed to utilize the duplex real-time PCR assays for the simultaneous detection of canine haemoparasites of Punjab state, India and their molecular characterization to reveal the genetic diversity, if any.

\section{Materials and methods}

\section{Study area}

The Punjab state is located in north-western India which extends from the latitudes $29.30^{\circ} \mathrm{N}$ to $32.32^{\circ} \mathrm{N}$ and longitudes $73.55^{\circ} \mathrm{E}$ to $76.50^{\circ} \mathrm{E}$ covering a geographical area of $50,362 \mathrm{~km}^{2}$ and lies between altitudes of 180 and $300 \mathrm{~m}$ above sea level. The current study was conducted in 11 districts of Central Plain Zone of Punjab viz., Amritsar $\left(31.63^{\circ} \mathrm{N}, 74.87^{\circ} \mathrm{E}\right)$, Barnala $\left(30.38^{\circ} \mathrm{N}, 75.54^{\circ} \mathrm{E}\right)$, Fatehgarh Sahib $\left(30.68^{\circ} \mathrm{N}, 76.41^{\circ} \mathrm{E}\right)$, Jalandhar $\left(31.32^{\circ} \mathrm{N}, 75.57^{\circ} \mathrm{E}\right)$, Kapurthala $\left(31.37^{\circ} \mathrm{N}, 75.37^{\circ} \mathrm{E}\right)$, Gurdaspur $\left(32.04^{\circ} \mathrm{N}\right.$, $\left.75.40^{\circ} \mathrm{E}\right)$, Ludhiana $\left(30.9^{\circ} \mathrm{N}, 75.85^{\circ} \mathrm{E}\right), \operatorname{Moga}\left(30.81^{\circ} \mathrm{N}\right.$, $\left.75.17^{\circ} \mathrm{E}\right)$, Patiala $\left(30.34^{\circ} \mathrm{N}, 76.37^{\circ} \mathrm{E}\right)$, Sangrur $\left(30.25^{\circ} \mathrm{N}\right.$, $\left.75.84^{\circ} \mathrm{E}\right)$ and $\operatorname{Tarn} \operatorname{Taran}\left(31.45^{\circ} \mathrm{N}, 74.93^{\circ} \mathrm{E}\right)$. The climate of the study area falls under warm semi-arid (BSh) and humid subtropical climate (Cfa) type as per the Koppen-Geiger climate classification [18].

\section{Collection of blood samples}

Blood samples $(n=338)$ were collected aseptically following the guidelines of animal care after approval from the Institute Animal Ethics Committee (IAEC/2018/1090-1125 dated 19.06.2018 and IAEC/2019/63-97 dated 29.04.2019) from suspected dogs. Animals presented at Multi-speciality Veterinary Hospital, Guru Angad Dev Veterinary and Animal Sciences University (GADVASU), Ludhiana and government/private veterinary clinics of selected districts with tick infestation, pyrexia, anaemia, cachexia, haemoglobinuria, posterior paralysis etc. were selected for the study. Approximately $2-5 \mathrm{~mL}$ of blood samples were collected in EDTA coated vacutainers, utilized for the preparation of thin blood smears and subsequently kept at $-20{ }^{\circ} \mathrm{C}$ till further use for DNA extraction.

\section{Microscopy}

Thin blood smears were prepared and stained with diluted Giemsa stain as per the protocol outlined by Juyal et al. [19] and examined microscopically. The intra-cellular piroplasms of Babesia spp. in RBCs, morulae of $E$. canis in monocytes or lymphocytes and gamonts of $H$. canis in the neutrophils or monocytes were identified morphologically. At least 100 oil immersion microscopic fields were tested before declaring the sample negative [10].

\section{Genomic DNA extraction}

For conducting the PCR assays, whole genomic DNA was extracted from the blood samples using QIAamp ${ }^{\circledR}$ DNA blood mini kit (Qiagen, Hilden, Germany) following the manufacturer's recommendations with minor modifications like increasing the centrifugation time by $30 \mathrm{~s}$ and eluting the DNA in a final volume of $100 \mu \mathrm{L}$ as per Singh et al. [20]. The eluted DNA was stored at $-20{ }^{\circ} \mathrm{C}$ till further use.

\section{Babesia vogeli and Ehrlichia canis duplex real-time PCR assay}

The $18 \mathrm{~S}$ ribosomal gene sequence of $B$. vogeli and virB9 gene sequence of $E$. canis were selected for synthesis of self-designed primers in a previous study carried out in our laboratory [17]. The criteria used for selection was compatibility of the primers, similar annealing temperature, variable amplicon size as well as $T_{m}$ values that can be interpreted with ease by melt-curve analysis. The laboratory standardized assay was set up in $20 \mu \mathrm{L}$ final volume using KAPA SYBR ${ }^{\circledR}$ FAST qPCR Kit Master Mix (2X) Universal (Kapa Biosystems, MA, USA) and consisted of 1X molar concentration of Master Mix, 0.5 pmol each of the respective primers for B. vogeli and E. canis and 0.75 pmol for primer of RPS5 as internal control [17]. The field samples were added @ $4 \mu \mathrm{L}$ per reaction as a template and final volume was made up to by nuclease free water (Thermo Scientific, MA, USA). The details of the primers used in the study areas under:

Forward primer (Bv-18S-337-F): 5'CTTAAAGGAAGG AGAAGTCGTAACA 3'

Reverse primer (Bv-18S-337-R): 5'CAGTCAAGCGGA GTTGCAAAT 3'

Forward primer (EC-virB9-234-F): 5'TGACCTGATATG CCGTAGCG 3'

Reverse primer (EC- virB9-234-R): 5'ACAAGGTAG TTGTCGCTTGTA 3' 
Forward primer (RPS5-141-F):5'TCACTGGTGAG/AAC CCCCT 3'

Reverse primer (RPS5-141-R):5'CCTGATTCACACGGC GTAG 3'

A 3-step PCR standardized protocol was selected with melt curve analysis and cycling conditions comprising of hot start at $95^{\circ} \mathrm{C}$ for $3 \mathrm{~min}, 30$ cycles of amplification comprising of denaturation at $95^{\circ} \mathrm{C}$ for $20 \mathrm{~s}$, annealing at $63.5^{\circ} \mathrm{C}$ for $20 \mathrm{~s}$ and extension and data acquisition at $72{ }^{\circ} \mathrm{C}$ for $40 \mathrm{~s}$ followed by melt or dissociation at $95{ }^{\circ} \mathrm{C}$ for $30 \mathrm{~s}, 65^{\circ} \mathrm{C}$ for $30 \mathrm{~s}$ and $95{ }^{\circ} \mathrm{C}$ for $30 \mathrm{~s}$. The analytical sensitivity of the assay and cross-reactivity studies were also carried out previously using the DNAs of B. gibsoni and $H$. canis in our laboratory [17].

\section{Babesia gibsoni and Hepatozoon canis duplex real-time PCR assay}

The $18 \mathrm{~S}$ ribosomal gene sequence of $B$. gibsoni and $H$. canis were selected for synthesis of self-designed primers in a previous study carried out in our laboratory [17] with the same selection criteria as discussed above. The PCR assay was set up as above with $1.25 \mathrm{pmol}$ of the respective primers for B. gibsoni; $2.5 \mathrm{pmol}$ for $H$. canis and $2.0 \mathrm{pmol}$ for $\beta$-actin as internal control [17]. The details of the primers used are as under:

Forward primer (Bg-18S-126-F): 5'CCGTCGTAGTCC TAACCATAAAC 3'

Reverse primer (Bg-18S-126-R): 5' TTCAGCCTTGCG ACCATAC 3'

Forward primer (Hc-18S-106-F):5' TCAACTTTATTA GAAGAGGCGCATT 3'

Reverse primer (Hc-18S-106-R):5'TTTTCACTTTGC GATTTGCTAAGTT 3'

Forward primer ( $\beta$-actin-218-F):5'CTGTCCCTGTAT GCCTCTG 3'

Reverse primer ( $\beta$-actin-218-R):5'ATGTCACGCACG ATTTCC 3'

A 3-step standardized PCR protocol was selected as above except for the annealing that was carried at $63.0^{\circ} \mathrm{C}$ for $20 \mathrm{~s}$ and extension at $72{ }^{\circ} \mathrm{C}$ for $20 \mathrm{~s}$. The analytical sensitivity of the assay and cross-reactivity studies were also carried out previously using the DNAs of $B$. vogeli and $E$. canis in our laboratory [17].

The results obtained from the duplex real-time PCR assays were compared with microscopy and the sensitivity and specificity of the developed assays were calculated. The association of related risk factors like age $(<6 \mathrm{~m} ; 6-12 \mathrm{~m}$; $>12 \mathrm{~m}$ ); sex (male and female); breed (defined and nondefined); season (summer, monsoon and winter) and locations (districts) with the prevalence of these haemoparasitic infections was determined.

\section{Molecular characterization, sequencing and analysis}

The positive representative samples from various districts by duplex real-time PCR assays were amplified by parasite specific conventional PCR assays using the same set of primes as described above but at final concentrations of $10 \mathrm{pmol} /$ reaction. The cycling conditions for performing the PCR assay for $B$. gibsoni and $H$. canis were: initial denaturation at $95^{\circ} \mathrm{C}$ for $3 \mathrm{~min}, 40$ cycles of denaturation $\left(95^{\circ} \mathrm{C}\right.$ for $\left.30 \mathrm{~s}\right)$, annealing $\left(62{ }^{\circ} \mathrm{C}\right.$ for $\left.30 \mathrm{~s}\right)$ and extension $\left(72{ }^{\circ} \mathrm{C}\right.$ for $\left.30 \mathrm{~s}\right)$ and thereafter final extension $\left(72^{\circ} \mathrm{C}\right.$ for $7 \mathrm{~min}$ ). For B. vogeli and E. canis the assay conditions were same as above with the exception of extension which was carried at $72{ }^{\circ} \mathrm{C}$ for $45 \mathrm{~s}$.

The PCR products for B. gibsoni, B. vogeli, E. canis and $H$. canis were purified using PCR Purification Kit (Real-Gene, CA, USA) as per manufacturer's protocol. The purified PCR products were subsequently cloned using CloneJET PCR cloning kit containing pJET1.2/blunt cloning vector (Thermo Scientific, USA) and the recombinant plasmids were transformed into $E$. coli $\mathrm{DH} 5 \alpha$ cells (Invitrogen, MA, USA). The positive clones (containing the inserts) were confirmed by colony PCR assays and plasmid DNA from the positive colonies were isolated by QIAprep ${ }^{\circledR}$ Spin Miniprep Kit (Qiagen) as per manufacturer's instruction and used as a template source for plasmid PCR assays. The recombinant plasmids were outsourced to DNA sequencing facility at Bioserve Biotechnologies Pvt. Ltd. (India) for sequencing by Sanger's sequencing method. The sequence data were aligned and analyzed by multiple sequence alignment using Clustal $\mathrm{W}$ method in Lasergene software (DNASTAR Inc., Madison, USA) and compared with homologues in the GenBank using nucleotide BLAST (NCBI).

\section{Statistical analysis}

The data obtained from microscopy and duplex real-time PCR assays were analysed by GraphPad for 2-tailed Fisher's exact test (https://www.graphpad.com/quickcalcs/ contingency 1.cfm) and kappa value (https://www.graphpad.com/ quickcalcs/kappa1.cfm). The strength of agreement between microscopy and duplex real-time PCR assays was interpreted as per Landis and Koch [21]. Furthermore, diagnostic sensitivity and specificity of these PCR assays in comparison to microscopy were analysed by MedCalc Software Ltd. Diagnostic test evaluation calculator version 20.008 (https:// www.medcalc.org/calc/diagnostic_test.php). The association of various risk factors with prevalence of tick-borne haemoparasitic infections were determined by the Chi-square and Fischer's exact test by SPSS software (Version 20) and probability of error was accepted up to $5 \%(p<0.05)$. 


\section{Results}

\section{Prevalence of canine tick-borne haemoparasitic infections}

The SYBR Green based duplex real-time PCR assays previously developed in our laboratory revealed the $\mathrm{T}_{\mathrm{m}}$ values for B. vogeli, E. canis and RPS5 as $89.5^{\circ} \mathrm{C}, 78.0^{\circ} \mathrm{C}$ and $85.0^{\circ} \mathrm{C}$, respectively while $\mathrm{T}_{\mathrm{m}}$ values for $B$. gibsoni, H. canis and $\beta$-actin were $81.5{ }^{\circ} \mathrm{C}, 75.5^{\circ} \mathrm{C}$ and $86.5^{\circ} \mathrm{C}$, respectively. $\mathrm{A}_{\mathrm{T}}$ value of 25 was set as the cut-off for positivity for both the assays as per our previous study. Similarly, the analytical sensitivity of PCR assays was $0.3125 \mathrm{pg} / \mu \mathrm{L}, 2.5 \mathrm{pg} / \mu \mathrm{L}, 0.15625 \mathrm{pg} / \mu \mathrm{L}$ and $0.039 \mathrm{pg} /$ $\mu \mathrm{L}$ for detection of B. vogeli, E. canis, B. gibsoni and $H$. canis, respectively.

An overall prevalence rate of $54.1 \%$ was recorded for these haemoparasitic infections by duplex real-time PCR assays, amongst which $H$. canis was the predominant parasite (25.4\%), followed by B. gibsoni (16.3\%), E. canis $(10.7 \%)$ and $B$. vogeli $(1.8 \%)$. Mixed infections of two (B. gibsoni and H. canis; E. canis and B. gibsoni; E. canis and H. canis; B. gibsoni and B. vogeli) and three (B. gibsoni, B. vogeli and $H$. canis; B. gibsoni, B. vogeli and E. canis; B. gibsoni, E. canis and H. canis) parasites were also recorded (Figs. 1, 2, details presented in Table 1). Microscopy revealed an overall prevalence rate of $10.7 \%$ which included B. gibsoni $(7.1 \%)$, E. canis $(1.8 \%), H$. canis $(1.5 \%)$ and $B$. vogeli $(0.3 \%)$ with no mixed infections (Table 1).

The sensitivity and specificity of duplex real-time PCR assays showed significant variation $(p$-value $<0.0001)$ by Fisher's exact test over microscopy, the "gold standard" test. The sensitivity $(95 \% \mathrm{CI})$ and specificity $(95 \% \mathrm{CI})$ of the $B$. vogeli and $E$. canis duplex real-time PCR assay was $100.00 \%$ (59.04 to $100.00 \%$ ) and $89.43 \%$ (85.60 to $92.52 \%$ ), whereas that of B. gibsoni and H. canis assay was $100.0 \%$ (88.06 to $100.00 \%$ ) and $63.75 \%$ (58.12 to $69.12 \%)$. The kappa (value $\pm \mathrm{SE}$ ) for the $B$. vogeli \& $E$. canis and B. gibsoni \& $H$. canis $\mathrm{PCR}$ assays were estimated at $0.259 \pm 0.08$ and $0.232 \pm 0.038$, respectively with "fair" strength of agreement for both the assays.

\section{Molecular characterization, sequencing and analysis}

Amplicons of 126 bp, 337 bp, 234 bp and 106 bp corresponding to $18 \mathrm{~S}$ rRNA gene for B. gibsoni, B. vogeli and
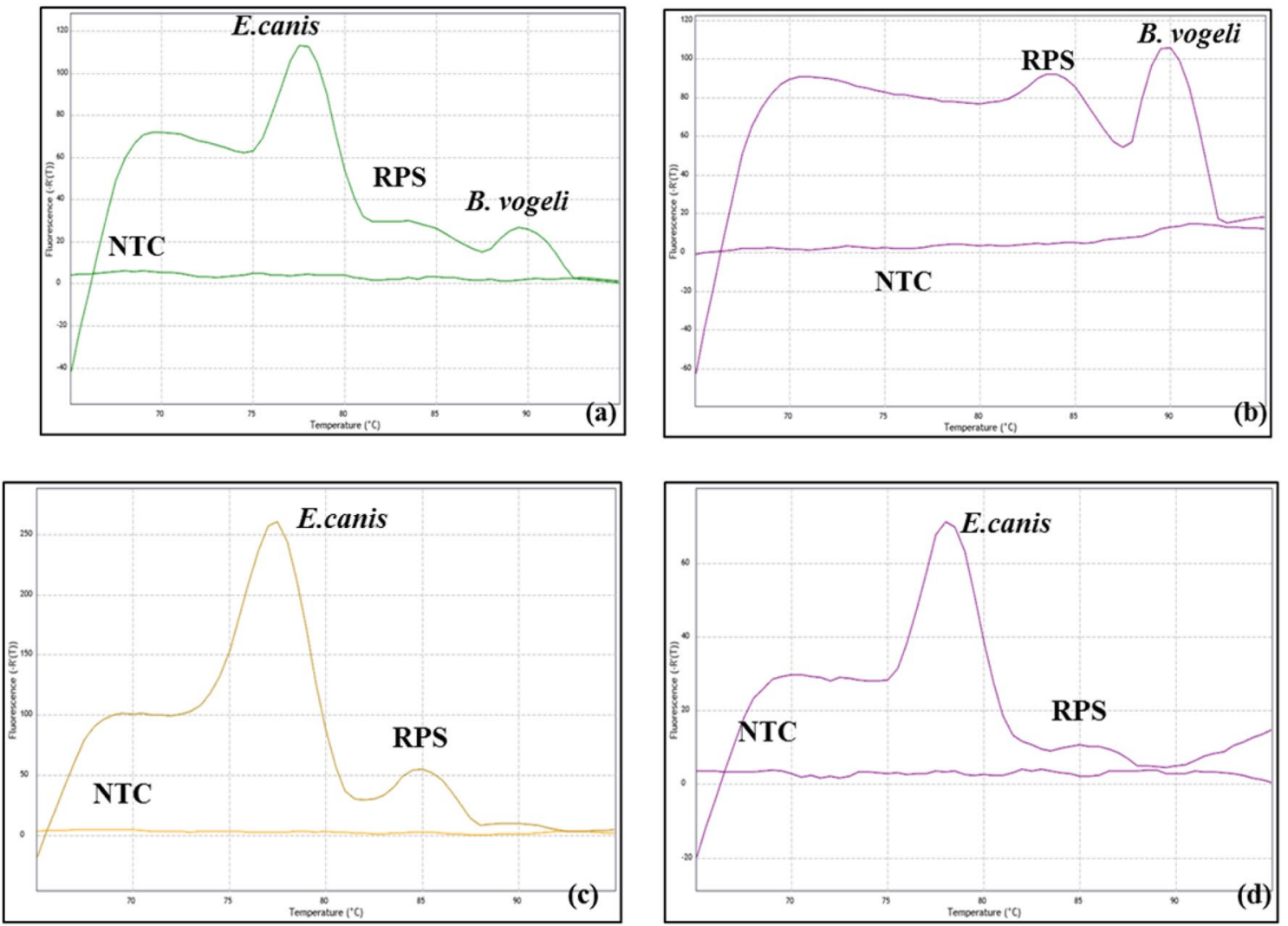

Fig. 1 a-d Field application of B. vogeli, E. canis and RPS 5 duplex real-time PCR assay 

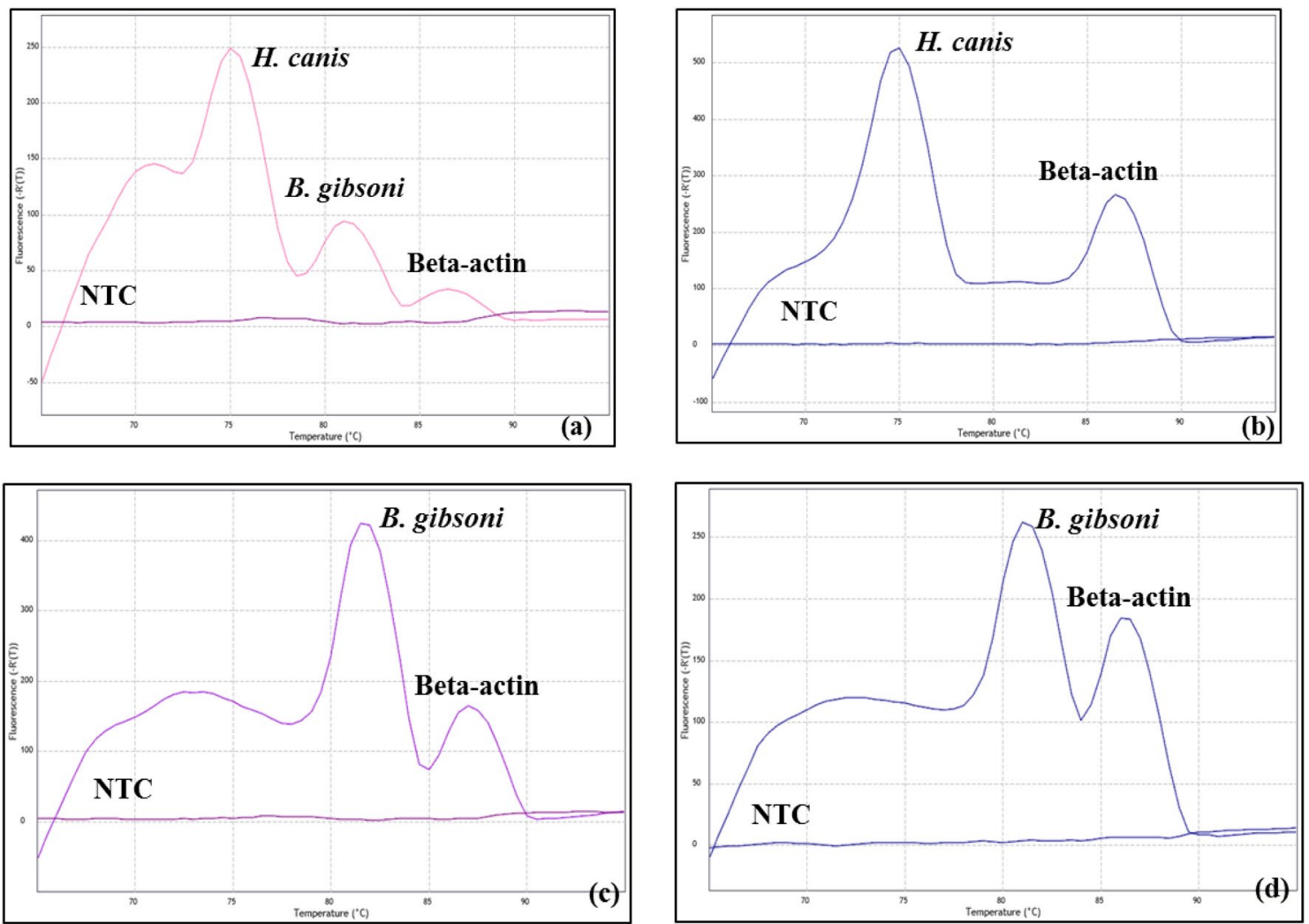

Fig. 2 a-d Field application of B. gibsoni, H. canis and $\beta$-actin duplex real-time PCR assay

Table 1 Prevalence of haemoparasites by microscopy and duplex real-time PCR assays

\begin{tabular}{|c|c|c|c|c|c|c|c|c|c|c|c|c|}
\hline Test & $\mathrm{N}$ & BV & BG & EC & $\mathrm{HC}$ & $\mathrm{M}_{1}$ & $\mathrm{M}_{2}$ & $\mathrm{M}_{3}$ & $\mathrm{M}_{4}$ & $\mathrm{M}_{5}$ & $\mathrm{M}_{6}$ & $\mathrm{M}_{7}$ \\
\hline Microscopy & 338 & $1(0.3)$ & $24(7.1)$ & $6(1.8)$ & $5(1.5)$ & $0(0.0)$ & $0(0.0)$ & $0(0.0)$ & $0(0.0)$ & $0(0.0)$ & $0(0.0)$ & $0(0.0)$ \\
\hline $\begin{array}{l}\text { Duplex real- } \\
\text { time PCR } \\
\text { assays }\end{array}$ & 338 & $6(1.8)$ & $55(16.3)$ & $36(10.7)$ & 86 (25.4) & $16(4.7)$ & $8(2.4)$ & $7(2.1)$ & $2(0.6)$ & $2(0.6)$ & $2(0.6)$ & $2(0.6)$ \\
\hline
\end{tabular}

Values in brackets indicate \%; BV, Babesia vogeli; BG, Babesia gibsoni; EC, Ehrlichia canis; HC, Hepatozoon canis

$M_{1}$ Mixed infection of BG \& HC, $M_{2}$ Mixed infection of EC \& BG, $M_{3}$ Mixed infection of EC \& HC, $M_{4}$ Mixed infection of BV, HC \& BG, $M_{5}$ Mixed infection of EC, BV \& BG, $M_{6}$ Mixed infection of BV \& BG, $M_{7}$ Mixed infection of EC, HC \& BG

$H$. canis and virB9 gene for $E$. canis were obtained, without any non-specific amplification by colony and plasmid PCR assays (Supplementary Fig. 1, 2). The sequences of six isolates of B. gibsoni (MZ321033, MZ321032, MZ413880, MZ467324, MZ457927 and MZ467328), three of B. vogeli (MZ320524, MZ458122 and MZ467325), one of E. canis (MZ326696) and nine of $H$. canis (MZ318674, MZ323362, MZ323363, MZ323361, MZ411573, MZ411572, MZ467327, MZ467326 and MZ458102) were published in the repository of GenBank, NCBI. The nucleotide sequences of local isolates of B. gibsoni, B. vogeli and $H$. canis revealed homology ranging from 7.6 to $100.0 \%$; $4.0 \%$ to $100.0 \%$ and $86.8 \%$ to $100.0 \%$ for the partial $18 \mathrm{~S}$ rRNA gene sequence while for E. canis $100 \%$ homology was observed for partial
virB9 gene when compared with other isolates (Supplementary Fig. 3). Based on this information a phylogenetic tree using bootstrap method was constructed and the phylogenetic linkage of various isolates for the respective parasites is presented (Fig. 3).

\section{Assessment of various risk factors}

Microscopic examination revealed significant $(p<0.05)$ association between sex of host and $B$. gibsoni infection with higher prevalence in males. Duplex real-time PCR assays revealed significantly $(p<0.05)$ higher prevalence of $H$. canis in German Shepherd dogs and significant $(p<0.05)$ 
(a)

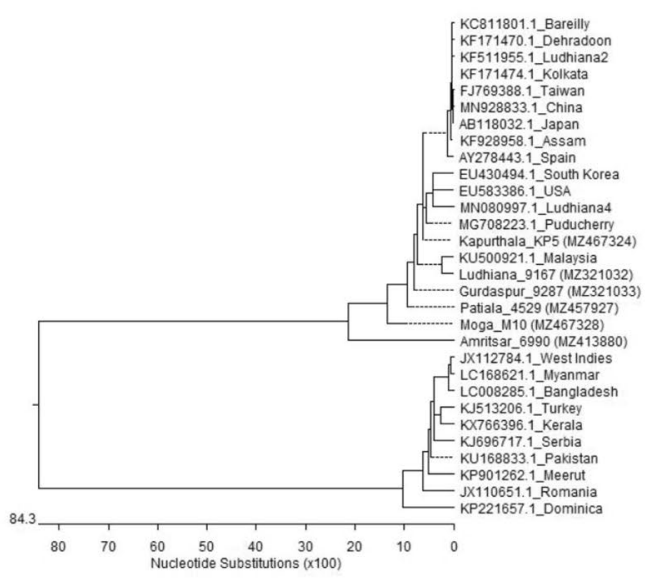

(b)

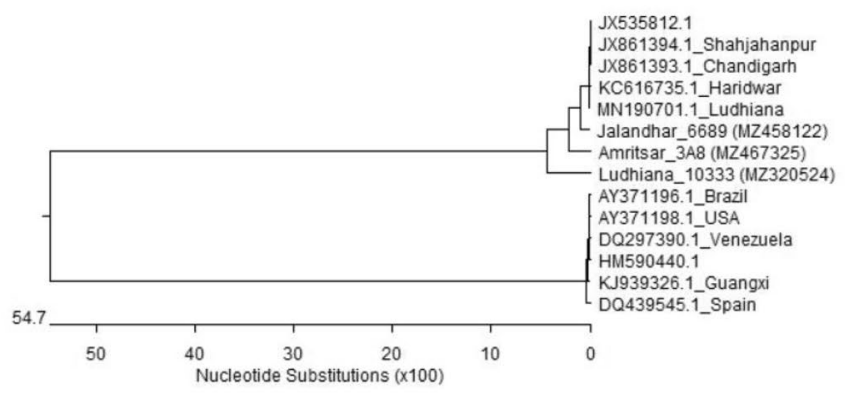

Jalandhar_11667 (MZ323361) Patiala_11198 (MZ323362) KU527125.1_Jalandh KX588232.1_Turkey FJ497022.1_Croatia KX712129.1 Romania LC556379.1_Malawi LC169075.2_Japan MK757814.1_Germany KU893126.1_Czech Republic AY461378.2_Spain DQ439543.1. Venezuela MF797806.1_Kerala2 KT267965.1_Malaysia KU527126.1_AAS Nagar EU289222.1_Taiwan KP182934.1-Philippines MH922768.1_Junagarh KX863669.1-Patiala1 KU527127.1_Hoshiarpu kUog6058.1 Luoniana1 udhian 4737 (M732669 AY205342.1 New Mexico-1 AY205341.1 Hawail AY205339. Arizona (c)

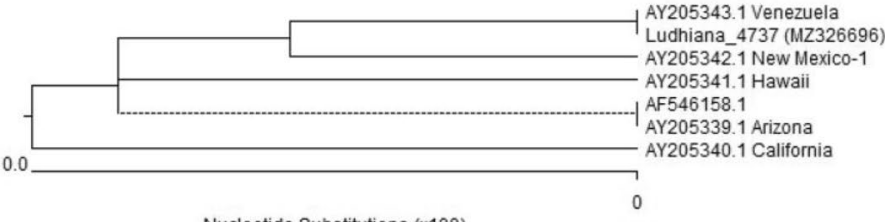

Nucleotide Substitutions (x100)

(d)

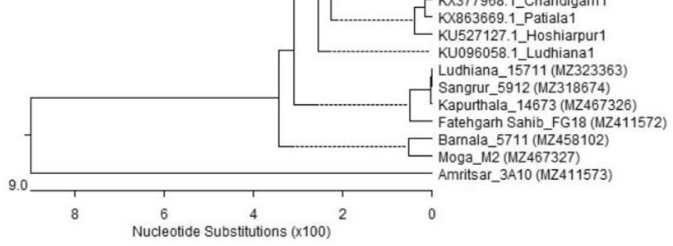

Fig. 3 Phylogenetic tree showing genetic relationships of a various isolates of B. gibsoni. b various isolates of $B$. vogeli. $\mathbf{c}$ various isolates of $E$. canis. d various isolates of $H$. canis

variation in E. canis infection among the seasons and locations (districts) of sample collection (details in Table 2).

\section{Discussion}

Although, demonstration of the parasite or its stages in samples of blood, cerebrospinal fluid, lymph node aspirates, etc. collected from suspected animal has been considered as the "gold standard" technique but microscopy suffers from the inherited disadvantage of low sensitivity and individual interpretation of results. Therefore, despite being a rapid and cost-effective technique, microscopy is not very useful for detection of latent/chronic cases with low parasite levels [7]. However, amplification of the parasitic DNA by nucleic acid-based assays in such cases gains importance because of their inherited property of high threshold detection limits with higher sensitivity and specificity over the conventional tests.
Published reports of molecular detection of canine haemoparasitic infections by various PCR assays from Punjab, India reveals the percent prevalence of B. gibsoni, B. vogeli, E. canis and $H$. canis infections in range of 15.4-15.42, $0.26-0.93,0.39-41.59$ and $0.26-30.0$, respectively [6-10, 13]. The wide variation regarding the prevalence of $E$. canis and $H$. canis might be attributed to the fact that Milanjeet et al. [6] utilized a nested PCR assay-based protocol while Singh et al. [10] used LAMP based assay, respectively in their studies. In the present study, the prevalence rates recorded for these haemoparasites were in the range as reported earlier.

The higher sensitivity (threshold detection limits) and specificity of duplex PCR based assays with an added advantage of simultaneous detection of more than one parasitic DNAs in the same tube renders them to be more cost effective with high field applicability [14]. Likewise, reports are available worldwide regarding simultaneous detection of multiple infections in dogs by different nucleic acid-based 
Table 2 Distribution of tick borne haemoparasitic infections of dogs in accordance with various risk factors

\begin{tabular}{|c|c|c|c|c|c|c|c|c|c|c|}
\hline \multirow[t]{2}{*}{ Risk factor } & \multirow[t]{2}{*}{ Parameter } & \multirow[t]{2}{*}{$\mathrm{N}$} & \multicolumn{4}{|c|}{ Microscopy (\%) } & \multicolumn{4}{|c|}{ Duplex real-time PCR assays (\%) } \\
\hline & & & BG & BV & $\mathrm{EC}$ & $\mathrm{HC}$ & BG & BV & $\mathrm{EC}$ & $\mathrm{HC}$ \\
\hline \multirow[t]{4}{*}{ Age } & $<6 \mathrm{~m}$ & 39 & $1(2.6)$ & $0(0.0)$ & $0(0.0)$ & $0(0.0)$ & $6(15.4)$ & $1(2.6)$ & $6(15.4)$ & $9(23.1)$ \\
\hline & $6-12 \mathrm{~m}$ & 35 & $2(5.7)$ & $0(0.0)$ & $1(2.9)$ & $0(0.0)$ & $4(11.4)$ & $0(0.0)$ & $3(8.6)$ & $10(28.6)$ \\
\hline & $>12 \mathrm{~m}$ & 264 & $21(8.0)$ & $1(0.4)$ & $5(1.9)$ & $5(1.9)$ & $45(17.0)$ & $5(1.9)$ & $27(10.2)$ & $67(25.4)$ \\
\hline & Pearson's $\chi^{2}$ value & - & 1.611 & 0.281 & 0.961 & 1.423 & 0.741 & 0.793 & 1.127 & 0.296 \\
\hline \multirow[t]{3}{*}{ Sex } & Female & 116 & $3(2.6)$ & $0(0.0)$ & $1(0.9)$ & $1(0.9)$ & $14(12.1)$ & $4(3.4)$ & $14(12.1)$ & $26(22.4)$ \\
\hline & Male & 222 & $21(9.5)$ & $1(0.5)$ & $5(2.3)$ & $4(1.8)$ & $41(18.5)$ & $2(0.9)$ & $22(9.9)$ & $60(27.0)$ \\
\hline & Pearson's $\chi^{2}$ value & - & $5.456^{*}$ & 0.524 & 0.844 & 0.462 & 2.290 & 2.835 & 0.373 & 0.855 \\
\hline \multirow[t]{9}{*}{ Breed } & German Shepherd & 49 & $3(6.1)$ & $0(0.0)$ & $1(2.0)$ & $0(0.0)$ & $7(14.3)$ & $0(0.0)$ & $8(16.3)$ & $20(40.8)$ \\
\hline & Labrador & 59 & $3(5.1)$ & $0(0.0)$ & $0(0.0)$ & $2(3.4)$ & $9(15.3)$ & $1(1.7)$ & $4(6.8)$ & $12(20.3)$ \\
\hline & Non-descript & 58 & $4(4.8)$ & $0(0.0)$ & $2(2.4)$ & $2(2.4)$ & $11(13.3)$ & $2(2.4)$ & $10(12.0)$ & $27(33.7)$ \\
\hline & Pit bull & 23 & $1(4.3)$ & $1(4.3)$ & $0(0.0)$ & $0(0.0)$ & $4(17.4)$ & $1(4.3)$ & $1(4.3)$ & $6(26.1)$ \\
\hline & Pomeranian & 15 & $2(13.3)$ & $0(0.0)$ & $1(6.7)$ & $0(0.0)$ & $4(26.7)$ & $0(0.0)$ & $3(20.0$ & $2(13.3)$ \\
\hline & Pug & 38 & $7(18.4)$ & $0(0.0)$ & $1(2.6)$ & $0(0.0)$ & $10(26.3)$ & $2(5.3)$ & $5(13.2)$ & $4(10.5)$ \\
\hline & Rottweiler & 12 & $1(8.3)$ & $0(0.0)$ & $1(8.3)$ & $0(0.0)$ & $2(16.7)$ & $0(0.0)$ & $3(25.0)$ & $3(25.0)$ \\
\hline & Others ${ }^{\#}$ & 59 & $3(5.1)$ & $0(0.0)$ & $0(0.0)$ & $1(1.7)$ & $8(13.6)$ & $0(0.0)$ & $2(3.4)$ & $11(18.6)$ \\
\hline & Pearson's $\chi^{2}$ value & - & 10.011 & 13.736 & 7.938 & 4.047 & 5.086 & 6.158 & 11.212 & $16.984^{*}$ \\
\hline \multirow[t]{4}{*}{ Season } & Summer & 128 & $11(8.6)$ & $0(0.0)$ & $3(2.3)$ & $0(0.0)$ & $25(19.5)$ & $5(3.9)$ & $17(13.3)$ & $33(25.8)$ \\
\hline & Monsoon & 113 & $9(8.0)$ & $1(0.9)$ & $2(18)$ & $2(1.8)$ & $20(17.7)$ & $1(0.9)$ & $15(13.3)$ & $28(24.8)$ \\
\hline & Winter & 97 & $4(4.1)$ & $0(0.0)$ & $1(1.0)$ & $3(3.1)$ & $10(10.3)$ & $0(0.0)$ & $4(4.1)$ & $25(25.8)$ \\
\hline & Pearson's $\chi^{2}$ value & - & 1.864 & 1.997 & 0.545 & 3.720 & 3.698 & 5.601 & $6.090^{*}$ & 0.040 \\
\hline \multirow[t]{13}{*}{ Location } & Amritsar & 27 & $2(7.4)$ & $0(0.0)$ & $1(3.7)$ & $0(0.0)$ & $5(18.5)$ & $1(3.7)$ & $5(18.5)$ & $8(29.6)$ \\
\hline & Barnala & 25 & $0(0.0)$ & $0(0.0)$ & $0(0.0)$ & $0(0.0)$ & $2(8.0)$ & $1(4.0)$ & $4(16.0)$ & $5(20.0)$ \\
\hline & Fathegarh Sahib & 30 & $1(3.3)$ & $0(0.0)$ & $1(3.3)$ & $0(0.0)$ & $4(13.3)$ & $0(0.0)$ & $2(6.7)$ & $9(30.0)$ \\
\hline & Gurdaspur & 28 & $2(7.1)$ & $0(0.0)$ & $0(0.0)$ & $0(0.0)$ & $4(14.3)$ & $0(0.0)$ & $0(0.0)$ & $9(32.1)$ \\
\hline & Jalandhar & 30 & $3(10.0)$ & $0(0.0)$ & $1(3.3)$ & $1(3.3)$ & $5(16.7)$ & $1(3.3)$ & $3(10.0)$ & $9(30.0)$ \\
\hline & Kapurthala & 28 & $1(3.6)$ & $0(0.0)$ & $0(0.0)$ & $1(3.6)$ & $3(10.7)$ & $0(0.0)$ & $1(3.6)$ & $4(14.3)$ \\
\hline & Ludhiana & 64 & $7(10.9)$ & $1(1.6)$ & $3(4.7)$ & $1(3.3)$ & $18(28.1)$ & $3(4.7)$ & $16(25.0)$ & $11(17.2)$ \\
\hline & Moga & 28 & $3(10.7)$ & $0(0.0)$ & $0(0.0)$ & $0(0.0)$ & $5(17.9)$ & $0(0.0)$ & $1(3.6)$ & $8(28.6)$ \\
\hline & Patiala & 31 & $4(12.9)$ & $0(0.0)$ & $0(0.0)$ & $2(6.5)$ & $6(19.4)$ & $0(0.0)$ & $1(3.2)$ & $8(25.8)$ \\
\hline & Sangrur & 26 & $1(3.8)$ & $0(0.0)$ & $0(0.0)$ & $0(0.0)$ & $2(7.7)$ & $0(0.0)$ & $3(11.5)$ & $9(34.6)$ \\
\hline & Tarn Taran & 31 & $0(0.0)$ & $0(0.0)$ & $0(0.0)$ & $0(0.0)$ & $1(4.8)$ & $0(0.0)$ & $0(0.0)$ & $6(28.6)$ \\
\hline & Pearson's $\chi^{2}$ value & - & 9.059 & 4.294 & 7.904 & 9.588 & 12.579 & 8.287 & $27.476^{*}$ & 7.504 \\
\hline & Total & 338 & $24(7.1)$ & $1(0.3)$ & $6(1.8)$ & $5(1.5)$ & $55(16.3)$ & $6(1.8)$ & $36(10.7)$ & $86(25.4)$ \\
\hline
\end{tabular}

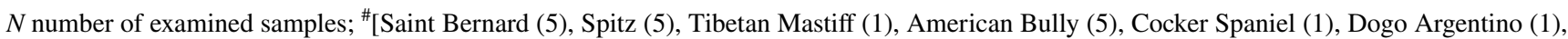
Bull Dog (2), Golden Retriever (4), Husky (3), Bull Terrier (2), Dachshund (6), Beagle (5), Greyhound (9), French Bully (2), Gaddi (3), French Mastiff (1), Pakistan Bully (1), Dalmatian (1), Doberman (1), Bully Pointer (3)]; *P $<0.05$

assays with higher threshold detection limits [22-24]. However, in Indian scenario, reports of multiplex PCR assaybased detection of canine diseases are available only from selected regions including states of Tamil Nadu [11], Kerala [12] and Punjab [13].

Among the two variants of real-time PCR assay i.e., TaqMan probe and SYBR green based protocols the former has the inherited disadvantage of higher cost due to individual probe requirement for each sequence [15, 16, 25]. The SYBR-Green methodology being cheaper, easy to use and having acceptable level of sensitivity in detection of
DNA of infectious agents make it an affordable diagnostic test. Hence, this protocol was applied in the present study for the simultaneous detection of the commonly prevalent canine haemoparasitic infection to be utilized by clinicians to save the life of pets.

Assessment of associated risk factors with the prevalence of these parasitic infections in recent past revealed non-significant variations with respect to age, sex and breed $[6,9,13]$. However, the present study reports significant variations in prevalence of $B$. gibsoni among sexes, $H$. canis among breeds and $E$. canis infection among the seasons and 
locations that can be attributed to the seasonal activity of vector tick. Similar to our findings, location wise significant variation in prevalence of $E$. canis infection has been recently reported by Kaur et al. [13].

Supplementary Information The online version contains supplementary material available at https://doi.org/10.1007/s11033-022-07286-4.

Acknowledgements We thank Dean, Postgraduate Studies, GADVASU for providing the necessary facilities. Thanks, are also due to the faculty members of Department of Veterinary Medicine and Teaching Veterinary Clinical Complex and field veterinarians for their help in the study.

Author contributions HS conceived the study and designed experiments. AMT, HP, RSS, NKS performed the experiments and wrote the manuscript. AMT, HS, NKS analysed the results. All authors read and approved the final version of the manuscript.

Funding The study was supported by the Department of Biotechnology, Ministry of Science \& Technology, New Delhi (BT/ADV/Canine Health/TANUVAS/2017-18).

\section{Declarations}

Conflict of interest The authors declare that they have no competing interests.

Ethical approval Animal protocols were approved by the Institute Animal Ethics Committee at College of Veterinary Science, Guru Angad Dev Veterinary and Animal Sciences University, Ludhiana vide reference IAEC/2018/1090-1125 dated 19.06.2018 (GADVASU/2018/IAEC/45/11) and IAEC/2019/63-97 dated 29.04.2019 (GADVASU/2019/IAEC/49/20).

\section{References}

1. Singh NK, Rath SS (2013) Epidemiology of ixodid ticks in cattle population of various agro-climatic zones of Punjab. Asian Pac J Trop Med 6:947-951

2. Kordick S, Breitschwerdt E, Hegarty B, Southwick K, Colitz C, Hancock S, Bradley J, Rumbough R, Mcpherson J, Maccormack J (1999) Coinfection with multiple tick-borne pathogens in a Walker Hound kennel in North Carolina. J Clin Microbiol 37:2631-2638

3. Shaw SE, Day MJ, Birtles RJ, Breitschwerdt EB (2001) Tickborne infectious diseases of dogs. Trends Parasitol 1:74-80

4. Esteve-Gasent MD, Snell CB, Adetunji SA, Piccione J (2017) Serological detection of tick-borne relapsing fever in Texan domestic dogs. PLoS ONE. https://doi.org/10.1371/journal. pone. 0189786

5. Abd Rani PAM, Irwin PJ, Coleman GT, Gatne M, Traub RJ (2011) A survey of canine tick-borne diseases in India. Parasit Vectors 4:141. https://doi.org/10.1186/1756-3305-4-141

6. Milanjeet SH, Singh NK, Singh ND, Singh C, Rath SS (2014) Molecular prevalence and risk factors for the occurrence of canine monocytic ehrlichiosis. Vet Med 59:129-136

7. Singh A, Singh H, Singh NK, Singh ND, Rath SS (2014) Canine babesiosis in North-western India: Molecular detection and assessment of risk factors. Biomed Res Int. https://doi.org/10. $1155 / 2014 / 741785$

8. Singla LD, Sumbria D, Mandhotra A, Bal MS, Kaur P (2016) Critical analysis of vector-borne infections in dogs: Babesia vogeli, Babesia gibsoni, Ehrlichia canis and Hepatozoon canis in Punjab, India. Acta Parasitol 61:697-706

9. Singh K, Singh H, Singh NK, Kashyap N, Sood NK, Rath SS (2017) Molecular prevalence, risk factors assessment and haemato-biochemical alterations in hepatozoonosis in dogs from Punjab, India. Comp Immunol Microbiol Infect Dis 55:53-58

10. Singh MD, Singh H, Singh NK, Singh NK, Kashyap N, Sood NK, Rath SS (2019) Development of loop-mediated isothermal amplification (LAMP) assay for detection of Hepatozoon canis infection in dogs. Ticks Tick-borne Dis 10:371-376

11. Azhahianambi P, Jyothimol G, Baranidharan GR, Aravind M, Ram Narendran R, Latha BR, Raman M (2018) Evaluation of multiplex PCR assay for detection of Babesia spp, Ehrlichia canis and Trypanosoma evansi in dogs. Acta Trop 188:58-67

12. Jain J, Lakshmanan B, Nagaraj HV, Praveena JE, Syamala K, Aravindakshan T (2018) Detection of Babesia canis vogeli, Babesia gibsoni and Ehrlichia canis by multiplex PCR in naturally infected dogs in South India. Vet Arhiv 88:215-224

13. Kaur N, Singh H, Sharma P, Singh NK, Kashyap N, Singh NK (2020) Development and application of multiplex PCR assay for the simultaneous detection of Babesia vogeli, Ehrlichia canis and Hepatozoon canis in dogs. Acta Trop 212:105713

14. Bell AS, Ranford-Cartwright LC (2002) Real-time quantitative PCR in parasitology. Trends Parasitol 18:337-342

15. Modarelli JJ, Ferro PJ, Perez de León AP, Esteve-Gasent MD (2019) TickPath Layerplex: adaptation of a real-time PCR methodology for the simultaneous detection and molecular surveillance of tick-borne pathogens. Sci Rep 9:6950

16. Huggins L, Massetti L, Schunack B, Colella V, Traub R (2021) Novel high-throughput multiplex qpcrs for the detection of canine vector-borne pathogens in the Asia-Pacific. Microorganisms 9:1092

17. Padmaja M (2021) Development of real-time multiplex PCR assay for detection of tick borne haemoparasites of dogs from south-western Punjab. M.V.Sc. Thesis submitted to Guru Angad Dev Veterinary and Animal Sciences University, Ludhiana, Punjab, India

18. Kottek M, Grieser J, Beck C, Rudolf B, Rubel F (2006) World Map of the Koppen-Geiger climate classification updated. Meteorol Z 15:259-263

19. Juyal PD, Singh NK, Singh H (2013) Diagnostic veterinary parasitology: an introduction, 1st edn. New India Publishing Agency, New Delhi, pp 30-32

20. Singh H, Jyoti HM, Singh NK, Rath SS (2012) Molecular detection of Anaplasma marginale infection in carrier cattle. Ticks Tick-borne Dis 3:55-58

21. Landis JR, Koch GG (1977) The measurement of observer agreement for categorical data. Biometrics 33:159

22. Duarte SC, Linhares GFC, Romanowsky TN, Neto O, Borges LMF (2008) Assessment of primers designed for the subspecies-specific discrimination among Babesia canis canis, Babesia canis vogeli and Babesia canis rossi by PCR assay. Vet Parasitol 152:16-20

23. Costa-Junior L, Zahler M, Rinder M, Ribeiro MFB, Rembeck K, Rabelo EML, Pfister K, Passos LMF (2012) Use of a real time PCR for detecting subspecies of Babesia canis. Vet Parasitol 188:160-163

24. Kamani J, Baneth G, Mumcuoglu Y, Waziri NE, Eyal O, Guthmann Y, Harrus S (2013) Molecular detection and characterization of tick-borne pathogens in dogs and ticks from Nigeria. PLoS Negl Trop Dis 7:108-115 
25. Kongklieng A, Intapan PM, Boonmars T, Thanchomnang $\mathrm{T}$, Janwan P, Sanpool O, Maleewong W (2015) Detection of Babesia canis vogeli and Hepatozoon canis in canine blood by a single-tube real-time fluorescence resonance energy transfer polymerase chain reaction assay and melting curve analysis. J Vet Diagn Invest 27:191-195
Publisher's Note Springer Nature remains neutral with regard to jurisdictional claims in published maps and institutional affiliations. 